\title{
Review
}

\section{Red skin, white masks: Rejecting the colonial politics of recognition}

\author{
Glen Sean Coulthard \\ University of Minnesota Press, Minneapolis, 2014, xi+229 pp., \\ ISBN: 978-0-8166-7965-2
}

Contemporary Political Theory (2016) 15, e52-e55. doi:10.1057/cpt.2015.20;

published online 5 May 2015

Many US and Canadian Indigenous scholars and activists critique and oppose capitalism as part of their decolonization efforts. Yet many also reject Marxism. There are numerous reasons, but the fact is, many Indigenous people do not see Marxism as a useful tool for or even relevant to their struggles. Furthermore, a history of antagonism between some Marxists and Indigenous Studies scholars and activists persists.

Despite all of Karl Marx's brilliance, elements of his theories just do not fit with the history and lived experiences of American Indians or the Indigenous populations in other liberal democratic settler colonial states such as Australia and New Zealand. And of course Marx was 'a man of his times,' which is a polite way of saying that he was a racist. Indeed, it is difficult to understate the racism at play when even Marx himself believed that the horrors of capitalism would at least have the benefit of dragging supposedly primitive, savage (that is, 'dark') people into the modern world, where they could then accept the blessings of socialism. Swap 'capitalism' for 'violent conquest' and 'socialism' for 'Jesus' and it suddenly starts to sound like the worst kind of imperial Christianity.

Glen Coutlhard is both Indigenous (Yellowknives Dene) and a leftist. And he is walking the line. On the one hand, Coulthard believes that Indigenous scholars who discount Marxism are making a mistake. However, he also asserts that some Marxist scholars have been belligerent, ignorant, dismissive and even racist in their rejection of Indigenous people's contributions to radical thought and politics, while some who are more sympathetic and well-meaning have often unwittingly adopted antiIndigenous postures.

Coulthard's goal is not to blame the participants in these debates. Rather, he aims to build a bridge between the two sides. He believes we must confront capitalism without sublimating Indigenous claims against colonialism, and confront settler colonialism in ways that oppose capitalism.

But Coulthard's loyalties are clear. His primary interest is using leftist theories to help Indigenous people decolonize. He also sincerely believes that Indigenous 
cultures, politics, societies and economies can help counter capitalism. However, he has little patience for narrow-minded Marxists whose opposition to capitalism blinds them to their own role in furthering the oppression of Indigenous people. He puts them on notice early in his debut book: 'By ignoring or downplaying the injustice of colonial dispossession, critical theory and left political strategy ... risk becoming complicit in the very structures and processes of domination that it ought to oppose' (p. 12). For example, Coulthard asks how a goal like the return of 'the commons' can be moral or ethical without recognizing that such commons actually belong to Indigenous peoples, whose cultures are not only informed by those lands, but who also advance ideas about the proper relationships between human beings and the natural world that are quite different from the ideas of most non-Indigenous cultures?

Although Coulthard rejects the notion that Marxism is a 'ready-made tool' for Indigenous people struggling against settler colonialism and capitalism, he does believe that Marxism, if carefully modified, can suit their purposes. To rehabilitate Marxist theory for the Indigenous context, Coulthard flips the relationship between colonialism and capitalism. Instead of looking at colonialism for insights into the nature of capitalism, Coulthard uses Marxist theory to understand how colonial dispossession has affected the colonized. Thus, rather than defining colonialism as a stepping stone in the development of capitalism, he wants to make colonialism the 'overarching lens of analysis.' (p. 11)

Coulthard switches the usual focus on capital relation to an emphasis on colonial relation. After all, colonialism is an ongoing reality for many Indigenous peoples around the world who continue suffering from state intervention and repression. In critiquing the normative development model, Coulthard wonders, "what are we to make of contexts where state violence no longer constitutes the regulative norm governing the process of colonial dispossession, as appears to be the case in ostensibly tolerant, multinational, liberal settler polities such as Canada?' (p. 15) If neither sheer violence nor the silent compulsion of capitalist forces explain it, then what accounts for the reproduction of capitalist hierarchies that find Indigenous peoples and societies at the bottom? As Coulthard points out: 'In the Canadian context, colonial relations of power are no longer reproduced primarily through overtly coercive means, but rather through the asymmetrical exchange of mediated forms of state recognition and accommodation.' In other words, for Indigenous peoples, capitalism is a function of colonialism, not vice versa.

By re-working Marx and examining the 'colonial-settler present' Coulthard hopes to: move past orthodox Marxism's economic reductionism; understand the innate injustice of colonial rule on its own terms instead of defining it as a byproduct of capitalism; overcome the overly materialistic and anti-ecological tendencies in Marx's works by centering dispossession and paying particular attention to placebased Indigenous experiences; and recognize that dispossession, rather proletarianization, has been the dominant process defining the relationship between Indigenous people and the Canadian state. 
Coulthard also works extensively with the ideas of Frantz Fanon. Coulthard employs Fanonian theory to explain how colonialism made the transition from naked aggression to colonial governmentality, which uses state recognition and accommodation to limit the freedoms of colonized people. As the title of Red Skins, White Masks suggests, Coulthard leans on Fanon's Black Skin, White Masks to make the case.

Coulthard cites Fanon's critique of the Hegelian master/slave dialectic to reveal how the liberal democratic politics of recognition and self-determination produces colonial thought, desire, and behavior among the colonized. Instead of an avenue toward freedom and dignity, recognition actually constitutes an arena of power in which colonial relations are produced and maintained. However, Coulthard is more critical of Fanon's interpretation of culture, via the latter's writings on negritude, and the limits Fanon placed on its ability to shape decolonization efforts. Through Fanon, Coulthard also discusses how, when state violence is not the main form of enforcement, colonialism relies on Indigenous people identifying, implicitly or explicitly, with asymmetrical and non-reciprocal forms of recognition that are either imposed or granted by the settler state and society.

Coulthard is especially critical of the politics of recognition. He opposes Indigenous people's quest for political and legal recognition from colonial power structures, and he critiques recognition schemes that acknowledge the collective rights and identities of Indigenous peoples only so long as they do not challenge the political and economic fabric of colonialism. Instead, he favors Indigenous people empowering themselves through individual and collective cultural practices that prefigure radical alternatives to colonial power.

Thus, Coulthard condemns transitional justice mechanisms, such as reconciliation commissions, state apologies, and commissions of inquiry, noting that Canadian colonialism is not in a transitional phase but is rather ongoing. Such mechanisms insulate colonial abuses by relegating them to past, and thus implicitly support current colonial abuses such as dispossession.

Coulthard also takes umbrage with the politics of reconciliation. He shows how since 1969, Canadian colonialism has moved from unconcealed action to a more disguised approach through state recognition and accommodation. All the while, dispossessions of Indigenous people's lands and self-determining authority continues. And once again Coulthard turns to Fanon as he champions the transformative role of ressentiment.

In the end, Coulthard advocates an Indigenous resurgence paradigm similar to the ones advanced by Indigenous scholars Taiaiake Alfred and Leanne Simpson. Coulthard champions direct action, opposition to capitalism, building through urban as well as rural Indigenous networks, overturning patriarchal norms spawned by colonialism, and ultimately moving beyond the nation state. Other theorists Coulthard considers along the way include Charles Taylor, Nancy Fraser, Dale Turner, Louis Althusser, Seyla Benhabib, Jean-Paul Sartre and Vine Deloria Jr. 
One of Red Skin, White Masks' strong points is Coulthard's narration and historical interpretation of Indigenous movements, including those of his own Dene people and the recent Idle No More protests. For example, he shows how Dene successfully challenged capitalism by pursuing political independence before being co-opted by recognition politics. During the 1970s and 1980s, Dene activists used Indigenous approaches and values to resist colonial expansion into their territories and to oppose capitalist extract resources schemes. Yet by the twenty-first century, many of the once radical activists had begun supporting the construction of diamond mines and the Mackenzie Valley Pipeline. An Indigenous struggle that was once informed by the land had transformed into a struggle for the land as recognition politics absorbed activists.

Meanwhile, Coulthard is careful to address potential criticisms. For example, he acknowledges that Fanon overstated the 'cleansing' role of anti-colonial violence, but finds Fanon's insights into the subjectifying nature of colonial recognition to be vital and relevant nevertheless. Coulthard also acknowledges that resentment and anger can take unhealthy turns that lead to disempowerment and internalized forms of violence. And he addresses not only concerns about essentialism restricting identity categories, but also shortcomings in Fanon and various Indigenous activists, by foregrounding the role patriarchy has played in colonialism.

For those working in Indigenous Studies, Red Skin, White Masks is a must read, as the author is in full dialog with many of the most important anti-colonial theorists in and out of the field. For political theorists less familiar with Indigenous Studies but want who to become more so, and especially for those political theorists who think they do not need to become more aware of Indigenous Studies, this is an important book. Indigenous Studies is amid a theoretical flourishing as many scholars produce exciting and important new ideas. Coulthard is not forwarding a simple synthesis, and his elbows can be sharp as he stakes out his positions. But regardless of the extent to which one agrees or disagrees with those positions, they are worth digesting and discussing, both on their own merits and as part of an important, global conversation that is emerging from Indigenous Studies.

Akim Reinhardt Towson University, Towson, MD 21252, USA 